\title{
Efficiency of the knowledge triangle policy in the EU member states: DEA approach
}

\author{
Katarzyna Tarnawska ${ }^{1 *}$ and Vasileios Mavroeidis ${ }^{2}$
}

\author{
* Correspondence: \\ katarzyna.tarnawska@polsca.pan.pl \\ ${ }^{1}$ Polish Science Contact Agency \\ PolsCA, Polish Academy of \\ Sciences, rue du Trône 98, B-1050 \\ Brussels, Belgium \\ Full list of author information is \\ available at the end of the article
}

\begin{abstract}
This paper aims to compare relative efficiency of the knowledge triangle policy in 25 EU member states providing evidence on the knowledge triangle technical efficiency calculated relying on output-oriented Data Envelopment Analysis (DEA) model assuming variable returns to scale (VRS). Moreover, the knowledge triangle efficiency indices are calculated, utilising the concept of actual and target inputs. Results obtained under output-oriented VRS model may signify overall effectiveness of the EU knowledge triangle policy. A more detailed analysis of output-oriented knowledge triangle efficiency indices reveals more differentiation among some countries. There are also significant variations among efficient decision-making units (DMUs) revealed through reference share analysis. Outcomes of this research may suggest the need of modification and/or strengthening of the knowledge triangle policy in some EU member states. The results obtained should however be treated with caution because they are influenced by the choice of variables.

Keywords: Knowledge-based economy, New Growth Theory, Knowledge triangle approach, DEA methodology
\end{abstract}

\section{Resumen}

Este trabajo tiene como objetivo comparar la eficiencia relativa del Programa del Triángulo del Conocimiento en 25 estados miembros de la UE calculada usando un modelo DEA, orientado a resultados, que asume rendimientos variables a escala. Los índices de eficiencia del triángulo del conocimiento se calcularon utilizando el concepto de insumos reales y de destino. Los resultados obtenidos con este modelo pueden interpretarse como evidencia de la efectividad a nivel global del Programa del Triángulo del Conocimiento de la UE. Un análisis más detallado de los índices de eficiencia reveló una mayor diferenciación entre los países miembros. Asimismo, detectamos variaciones significativas en la eficiencia de DMUs con un análisis de referencia compartida. Los resultados de esta investigación sugieren la necesidad de modificación y/o fortalecimiento del Programa del Triángulo del Conocimiento en algunos estados miembros de la UE. Sin embargo, los resultados obtenidos deben ser tratados con precaución ya que son sensitivos a nuestra elección de variables incluidas en el modelo.

\section{Springer}

(c) 2015 Tarnawska and Mavroeidis. Open Access This article is distributed under the terms of the Creative Commons Attribution 4.0 International License (http://creativecommons.org/licenses/by/4.0/), which permits unrestricted use, distribution, and reproduction in any medium, provided you give appropriate credit to the original author(s) and the source, provide a link to the Creative Commons license, and indicate if changes were made. 


\section{Résumé}

Cet article vise à comparer l'efficacité relative de la politique du triangle de la connaissance dans 25 pays membres de l'UE. II documente l'efficacité technique du triangle de la connaissance calculée suivant le modèle de la méthode d'enveloppement (DEA) axé sur les résultats qui suppose des rendements d'échelle variables (VRS). De plus, les indices d'efficacité du triangle de la connaissance sont calculés en utilisant le concept d'intrants actuels et cibles. Les résultats obtenus suivant le modèle VRS axé sur les résultats peuvent signifier une efficacité totale de la politique du triangle de la connaissance de I'UE. Une analyse plus détaillée révèle des différenciations entre certains pays.

Des variations significatives se notent également entre les DMU efficients obtenus à partir de l'analyse de partage de référence. Les résultats de cette recherche suggèrent le besoin de modification ou de renforcement de la politique du triangle de la connaissance dans certains pays membres de l'UE. Ces résultats doivent cependant être traités avec précaution car ils sont influencés par le choix des variables.

\section{摘要}

本文旨在比较欧盟 25 个成员国知识三角政策的相对效率,为依据假定产出导向的 可变规模报酬(VRS)DEA模型计算知识三角技术效率提供证据。此外,本文还利用 实际和目标投入的概念计算知识三角效率指数。按照产出导向的VRS模型得到的 结果可能意味着欧盟知识三角政策的整体效果。对产出导向的知识三角效率指 标的更详细分析揭示在一些国家之间更多的差异。通过参考份额分析也揭示了 在高效DMUs之间也存在着显著的变化。这项研究的结果建议有必要修改和/或 加强在一些欧盟成员国的知识三角政策。然而我们应当谨慎地对待所得到的结 果,因为它们受变量选择的影响。

\section{Аннотация}

Целью настоящей работы является сравнение относительной эффективности стратегии «Треугольник знаний» в 25 странах Евросоюза, что позволит рассчитать производительность треугольника знаний на основании анализа среды функционирования в зависимости от выпуска продукции с учетом меняющегося эффекта масштаба.

Кроме того, были рассчитаны показатели эффективности треугольника знаний с использованием фактических и целевых значений выпуска продукции. Полученные результаты, учитывающие меняющийся эффект масштаба в зависимости от объема выпуска продукции, позволяют охарактеризовать общую эффективность стратегии «Треугольник знаний» в ЕС. Более детальный анализ показателей эффективности треугольника знаний, учитывающих объемы выпуска продукции, раскрывает значительные различия между некоторыми странами. Дополнительно, на основании оценки относительных долей участников были выявлены существенные различия среди эффективных хозяйствующих субъектов. Результаты данного исследования могут указать на необходимость модификации и/или усиления стратегии «Треугольник знаний» в некоторых странах Евросоюза. Полученные результаты, однако, не должны вызывать сомнений, т.к. они получены с учетом моделей множественного выбора. 


\section{Resumo}

Esse artigo visa comparar a eficiência relativa da política do Triangulo do Conhecimento em 25 países membros da União Européia fornecendo evidências sobre a eficácia técnica do Triangulo do Conhecimento, calculada com base no modelo de Análise Envoltória de Dados - DEA considerando os rendimentos variáveis de escala (VRS-Variable Returns to Scale). Além disso, os índices de eficiência do Triangulo do Conhecimento são calculadas usando o conceito de entradas de saídas. Os resultados obtidos sob o modelo de VRS podem significar uma eficácia global da política do Triangulo do Conhecimento na União Européia. Uma análise mais detalhada dos índices de eficiência do Triangulo do Conhecimento, com base nas orientações dos outputs, revelam uma diferenciação maior entre alguns países. Há também variações significativas entre as medidas comparativas de eficiência de Unidade de Tomada de Decisão (Decision Making Unit - DMU), revelada através de análises compartilhadas. Os resultados dessa pesquisa podem sugerir a necessidade de modificação e/ou fortalecimento da política do Triangulo do Conhecimento em alguns países membros da União Européia. Os resultados obtidos devem ser, contudo, tratados com cuidado devido à influência da escolha das variáveis.

\section{Multilingual abstract}

Please see Additional file 1 for translation of the abstract into Arabic.

\section{Introduction}

The notion of knowledge-based economy is gaining its recognition among both economists and policymakers at the EU level. Economies based on efficient usage of knowledge have almost unlimited opportunities for growth. Exploiting knowledge is nevertheless not attributed to one sector of economy but requires cooperation of different branches, especially higher education and business. Special expectations are made for educational system which is not only provider but also recipient of knowledge-consuming solutions strengthening the ability of innovation absorption by the society.

From a policy-making point of view, investment in $R \& D$, education and innovation should not be treated separately. Therefore, in order to enhance investment efficiency, the knowledge triangle approach has been developed in the EU. It relies on mutually reinforcing policies addressed to education, research and innovation. Examination of the knowledge triangle efficiency policy is essential for designing appropriate policy adaptations leading to transformation towards the knowledge-based economy.

This paper aims to investigate relative efficiency of the knowledge triangle approach in $25 \mathrm{EU}$ member states. It provides evidence on the knowledge triangle pure technical efficiency calculated basing on output-oriented Data Envelopment Analysis (DEA) model and presents the analysis of the scope of efficient member states to be a benchmark for inefficient ones. Moreover, utilising the concept of actual and target inputs, individual output-oriented knowledge triangle efficiency indices are computed to suggest more detailed policy recommendations.

The study is organised as follows: the first part gives insights into the knowledgebased economy, then the concept of the knowledge triangle is introduced. Next part provides an overview of DEA methodology. It is followed by analysis of variables and discussion of empirical results. 


\section{Knowledge-based economy and the knowledge triangle}

\section{Economic theory and rationale for knowledge-based economy}

In modern societies, economic growth and prosperity are based on capacity and ability to produce and use new knowledge. This leads to development of the knowledge society which is characterized by a high participation of its members in the production and reproduction of knowledge (Shapiro et al. 2007). According to Organisation for Economic Co-operation and Development (OECD) (1996), knowledge-based economy is directly based on the production, distribution and use of knowledge and information. Relationship between traditional economics and the knowledge-based economy is reflected in the new growth theory.

The core statement of the new growth theory is that knowledge drives growth. Classical growth theories treated technology as a given while capital accumulation and labour force improvement were the major sources of growth. The new growth theory incorporates technology into a model of markets' functioning and hence is called 'endogenous' growth theory. This theory puts emphasis on the fact that new knowledge is crucial for the growth and explains the rationale of a knowledge-based economy. Knowledge makes growth possible because it is subject to increasing returns. The reason is that knowledge is a non-rival good meaning that many people may use it at one time without depriving others of their use. Unlike public goods, knowledge is at least partially excludable due to property rights.

Increasing returns related to knowledge creation have important implications for economic growth (Cortright 2001). First of all, opportunities for growth are almost unlimited. Economies may develop by steady improvement of knowledge on how to produce more and better with smaller amounts of physical resources. There are nevertheless some challenges associated with increasing returns. Due to the fact that social benefits and private costs of new knowledge diverge, the right price signals may be absent. Lack of a full excludability of knowledge causes that knowledge providers earn less than the social value of knowledge that they produce which in consequence results in under-investment in knowledge. Property rights are a popular remedy for this drawback, but at the same time, they may hinder further development of technology. Knowledge-based economies may also lead to monopolistic competition where competition is based not on cutting prices but on augmenting product characteristics.

The new growth theory has the following major implications for economic development policies (Cortright 2001):

- Creation of knowledge should take place not only at universities but also carried out by business,

- States and communities can influence their economic growth,

- Due to a path dependence, current local base of knowledge and expertise is crucial for future growth,

- Both scientific research and minor ideas developed at the workplace are important for economic growth what means that everyone can create knowledge and

- Knowledge-based growth is self-reinforcing, a proper high-growth strategy may encourage business sector to make more investment in research and development. 


\section{Building blocks of knowledge-based economy-higher education}

OECD report on the human and social capital (OECD 2001) claims that

Changing economic and social conditions have given knowledge and skills-human capital-an increasingly central role in the economic success of nations and individuals. Information and communications technology, globalisation of economic activity and the trend towards greater personal responsibility and autonomy have all changed the demand for learning. The key role of competence and knowledge in stimulating economic growth has been widely recognised by economists and others.

Traditionally, three factors of production are identified: land, labour and physical capital. Since the early 1960s, the role of the quality of labour has started to grow giving rise to the concept of human capital. OECD (2001) defines human capital as 'the knowledge, skills, competencies and attributes embodied in individuals that facilitate the creation of personal, social and economic well-being'. Human capital has a positive impact on economic growth through knowledge creation and dissemination. Evidence shows that for OECD countries, human capital formation by tertiary education is especially important as it supports economic growth (OECD 2001). There is a tendency to shift from a traditional definition of innovation understood as new or improved products, services, processes or improved organisational strategies towards innovation described as 'the ability of individuals, companies and entire nations to continuously create their desired future' (Kao as quoted in European Commission 2009a). This new approach to innovation emphasizes that education and training are vital for innovation and knowledge creation. Innovation is not therefore limited to research and development activities, but it takes place in the society basing on widely spread knowledge of its members. The role of non-technological innovation is growing; as a result, the importance of creativity is increasing as well as of human capital and talented people. Creativity and innovation are interlinked because creative capacities, problem solving, communication and teamworking belong to 'soft innovation skills'; creativity is also more and more often regarded as a production factor. This gives a new role for education system whose new task should be boosting creativity which is required not only in a workplace but is crucial for active citizen and consumer (Shapiro et al. 2007).

There is a growing awareness that higher education is one of the key institutions in a knowledge-based economy (Maassen and Stensaker 2011). European Commission noticed that

Modernisation of Europe's universities involving their interlinked roles of education, research and innovation, has been acknowledged not only as a core condition for the success of the broader Lisbon Strategy, but as part of the wider move towards an increasingly global and knowledge-based economy (European Commission 2006).

There is the link between knowledge and economic productivity and growth through (Shapiro et al. 2007):

- Innovation processes leading to the creation and application of new knowledge or application of existing knowledge in a novel way and

- Education and training enabling production and application of new knowledge or application of existing knowledge in a novel way. 
The role of user-driven innovation in economic growth is also augmenting (Porter 1990). Though innovations cannot succeed without demand, the demand side of the innovation market has been for many years neglected (Edler 2009). Demand for innovation refers to the desire or preference to purchase an affordable product or service. Preferences and attitudes of consumers may be shaped by education which supports in this way demand for innovation.

Educational system responds as well to demand for new skills and competences raised by business. Common education industry projects, close collaboration of universities and business as well as development projects should be therefore promoted as useful tools of identification business sector needs and providing the required knowledge and skills (Shapiro et al. 2007).

The knowledge triangle-a policy-making instrument strengthening the EU knowledge economy

Transition to a knowledge-based economy was a principal aim of the Lisbon Strategy. The European Commission noted the following difficulties associated with the knowledge policy (Hervás Soriano and Mulatero 2009):

- The lack of innovation and entrepreneurial culture in research and higher education,

- A lack of investment, in particular private investment, in research and development and

- The difficulty Europe has in transforming R\&D results into commercial opportunities.

Despite efforts supporting investment in $R \& D$, education and innovation, there is still little progress towards transition to a knowledge-based economy. One of the reasons could be that all these areas have been addressed separately. It especially refers to education. While there have been attempts to bring together the research and innovation agendas, education still seems to be dealt with mainly separately (Hervás Soriano and Mulatero 2009).

The knowledge triangle concept may be regarded as a political response to this problem. This approach, illustrated in Fig. 1, integrates research, education and innovation

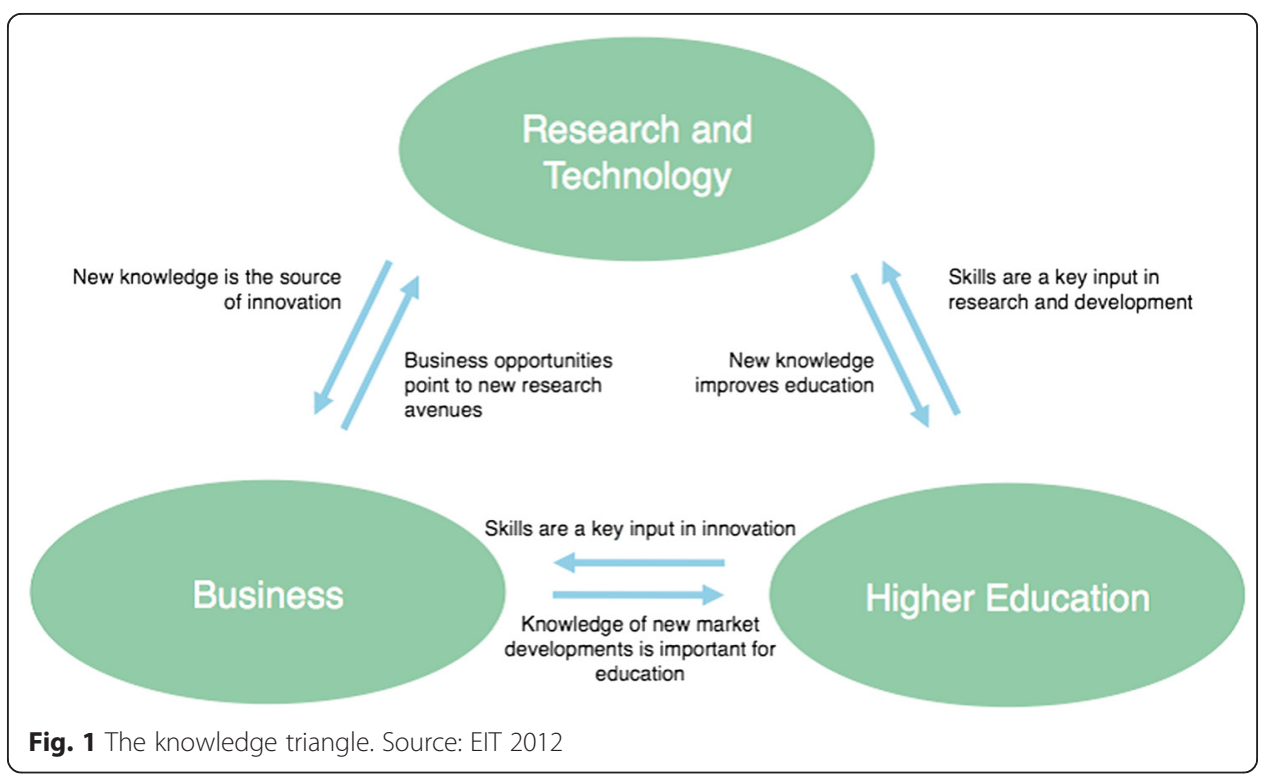


acknowledging positive externalities between them. For example, a skilled workforce is the basis for undertaking research and development activities, as well as for bringing new products and processes to the market. In return, knowledge and new market developments should have a feedback loop to educational programmes. Similarly, new knowledge is the source of innovation and, in return, new market prospects for innovation can point towards new avenues for research.

Potočnik (2009) states that 'the knowledge triangle needs universities [...]. They are primary source of new knowledge generation as well as important providers of applied knowledge which supports business research and innovation'. The council of the European Union has recognised that 'the specific function of education as the basis of the knowledge triangle needs to be further developed' (Council of the EU 2009).

There is also a need to maintain strong connection between research activities and teaching. Not only universities but also 'non-academic' institutions need qualified research personnel that should be trained at universities. Strong relations of universities with the industry are necessary to create better employment opportunities for graduates while mobility of people between universities and companies enables transfer of knowledge (European Commission 2004). Staff mobility between the university and business sector and university-business cooperation should become an important part of universities' education, research and innovation strategies (Council of the EU 2009).

The knowledge triangle approach stresses that research output should be integrated into education. Innovations influences also education system ameliorating both its content and improving the learning environment. The knowledge triangle concept puts also emphasis on the role of education in fostering innovation recognising its role in creation of demand for innovation through educating consumers as adopters of innovative goods and services (Hervás Soriano and Mulatero 2009).

Table 1 presents EU policy framework related to the knowledge triangle. It is based on Integrates Guidelines for 2008-2010 and the Community Lisbon Programme for the same period.

The Council of the European Union affirms that 'the concept of the knowledge triangle, relates to the need for improving the impact of investments in the three forms of activity-education, research and innovation-by systemic and continuous interaction'

Table 1 The knowledge triangle in EU policy

\begin{tabular}{|c|c|c|}
\hline & $\begin{array}{l}\text { Knowledge supply and demand (strengthening } \\
\text { the vertices of the knowledge triangle) }\end{array}$ & $\begin{array}{l}\text { Knowledge circulation (linkages between } \\
\text { vertices of the knowledge triangle) }\end{array}$ \\
\hline \multirow{2}{*}{$\begin{array}{l}\text { Research \& } \\
\text { development }\end{array}$} & $3 \%$ investment target & \multirow{2}{*}{$\begin{array}{l}\text { Bringing together public research } \\
\text { institutions with private innovators }\end{array}$} \\
\hline & Creation of European research area & \\
\hline \multirow[t]{3}{*}{ Innovation } & Improvement framework condition for innovation & $\begin{array}{l}\text { Creation and development of innovation } \\
\text { poles, network and incubators }\end{array}$ \\
\hline & Strengthening the European industrial base & $\begin{array}{l}\text { Promotion new technological initiatives } \\
\text { based on Public Private Partnerships (PPPs) }\end{array}$ \\
\hline & Promotion of environmental-friendly technologies & $\begin{array}{l}\text { Establishment of the European Institute for } \\
\text { Technology (EIT) }\end{array}$ \\
\hline \multirow[t]{2}{*}{ Education } & $\begin{array}{l}\text { Development and strengthening education } \\
\text { institutions and creation new ones }\end{array}$ & Promotion of a more entrepreneurial culture \\
\hline & $\begin{array}{l}\text { Expansion and improvement of investment } \\
\text { in human capital and raising the quality of } \\
\text { education and training }\end{array}$ & $\begin{array}{l}\text { Development of education responding new } \\
\text { occupational needs, key competences and } \\
\text { future skill requirements }\end{array}$ \\
\hline
\end{tabular}


(Council of the EU 2009). Policies addressed to education, research and innovation should be mutually reinforcing to ensure the development of a fully functional knowledge triangle and to speed up the transition towards a true knowledge-based economy and society (Council of the EU 2009).

\section{DEA methodology DEA approach}

The concept of knowledge is hard to quantify. The same refers to the knowledge-based economy and the knowledge triangle. This is crucial however to measure the effectiveness of activities undertaken in the framework of a policy design to develop evidencebased policy recommendations (Karahan 2012).

This study offers measurement of the knowledge triangle policy performance with DEA. DEA is a non-parametric frontier methodology developed by A. Charnes, W. Cooper and E. Rhodes. It is based on distance functions which allow to describe multiinput, multi-output production technology without the need to specify a behavioural objective (cost minimisation or profit maximisation). An input distance function is looking at a minimal proportional contraction of the input vector, given an output vector. An output distance function considers a maximal proportional expansion of the output vector, given an input vector (Coelli et al. 2005). DEA does not require a priori definition of the production or cost functions (da Cruz and Marques 2014). It is an effective approach to assess efficiency of organisations when traditional approaches to efficiency or productivity measurement either fail or are difficult or impossible to apply what is typical within the public sector or if the production processes are not welldefined (Golany and Roll 1989).

DEA is a mathematical programming-based approach for measuring relative efficiency of peer entities called decision-making units (DMUs) that have multiple and identical inputs and outputs. With linear programming methods, non-parametric piece-wise surface (or frontier) is constructed over the data, efficiency measures are calculated relative to this surface (Coelli et al. 2005). It is assumed that a DMU uses a set of resources (inputs) which it transforms into a set of outcomes (outputs). Therefore, DEA may be applied to governmental agencies, not-for-profit organisations as well as business firm (Cooper et al. 2011) and macroeconomic analyses (see, for example Chien and $\mathrm{Hu} 2007$ or Tong 1997). In this study, $25 \mathrm{EU}$ member states are included to the analysis as the DMUs, the smallest member states: Cyprus, Luxembourg and Malta were excluded as being not homogenous with bigger member states.

DEA is intended as a method for performance evaluation and benchmarking against best practice (Cook, Tone and Zhu 2014). Therefore, it is a useful tool in operations management because while statistical regressions fail to explain the behaviour of individual DMUs, DEA overcomes this difficulty.

It is also important to make distinction between technical, allocative and overall efficiency (see, e.g. Thanassoulis 2001 on this subject). In this paper, technical efficiency only will be analysed. Technical output efficiency reflects the extent to which the output levels of the DMU concerned can be raised through improved performance, and no additional resource while maintaining its output mix. Technical input efficiency 
illustrates the extent to which the input levels of the DMU concerned can be lowered through improved performance and no output reduction while maintaining its input mix (Thanassoulis 2001).

Selection of the most appropriate DEA model is one of the most crucial tasks before carrying out the DEA analysis. In this study, output-oriented variable returns to scale (VRS) model will be used to get more insights into a problem under investigation (see Appendix for its formal presentation).

DEA methodology has been applied in the area of the knowledge-based economy. It has been widely used to measure national innovation system efficiency. A comprehensive comparative study of the literature on the subject was carried out by Kotsemir (2013). He reviewed 11 studies focusing on the choice of DMUs, input and output variables and DEA models. Analyses on the R\&D sector and information society at the regional level were carried out by Aristovnik (2014b). The same scholar investigated efficiency of the higher education systems at a national level (Aristovnik 2012, Aristovnik 2014a).

\section{Efficiency indices}

Besides the efficiency scores that provide a single index, it is possible to look more precisely on target output levels and the amount of adjustment of output for DMUs. ${ }^{1}$ Apart from a radial adjustment, there exist as well a second stage shift called slack adjustment (see Appendix). The slacks represent further potential of output increase in some dimensions, given that the DMUs can change the relative mix of outputs produced (Torgersen et al. 1996). As the amount of adjustments-being the summation of radial and slack adjustments-increases, it implies a lower efficiency of the national knowledge triangle. Basing on the adjustment, target output levels may be identified and compared to observed (actual) output levels. In this way, three output-oriented knowledge triangle efficiency indices may be constructed for each DMU: hightechnology export-oriented knowledge triangle efficiency index (EKTEI), scientific and technical publication-oriented knowledge triangle efficiency index (PKTEI) and nontechnological innovation-oriented knowledge triangle efficiency index (NKTEI). They are defined as follows:

$$
\begin{aligned}
& \operatorname{EKTEI}_{\mathrm{DMU}_{\mathrm{jo}}}=\frac{\text { Target export output } \mathrm{DMU}_{\mathrm{jo}}}{\text { Actual export output } \mathrm{DMU}_{\mathrm{jo}}} \\
& \mathrm{PKTEI}_{\mathrm{DMU}_{\mathrm{jo}}} \frac{\text { Target publication output } \mathrm{DMU}_{\mathrm{jo}}}{\text { Actual publication output } \mathrm{DMU}_{\mathrm{jo}}} \\
& \mathrm{NKTEI}_{\mathrm{DMU}_{\mathrm{jo}}}=\frac{\text { Target non-technical innovation output } \mathrm{DMU}_{\mathrm{jo}}}{\text { Actual non-technical innovation output } \mathrm{DMU}_{\mathrm{jo}}}
\end{aligned}
$$

The above output-oriented knowledge triangle efficiency indices range between 0 and 1. Efficiency score which achieves 1 means that a DMU reaches the target output based on the frontier, when this score is close to 0, efficiency is extremely low. The indices allow to identify strengths and weaknesses of each DMU with respect to various knowledge triangle efficiencies. A DMU may experience a significant weakness concerning one or more output-oriented knowledge triangle efficiency indices. Comparison of indices is more useful for policymakers than looking at the pure technical efficiency only. 


\section{DMU discrimination methodology}

There is a high risk of a big number of efficient DMUs when there is a small number of observations in comparison with the sum of inputs and outputs. In order to discriminate between technically efficient DMUs, a methodology developed by Torgersen et al. (1996) will be used. It is based on calculation of the reference-share which takes into account not only a number of times when efficient DMU is a benchmark but also the values of $\lambda$ (see Appendix for explanation).

For each efficient DMU $j$ which acts as a referent for inefficient DMU $i$, the fraction of the total aggregated potentials for increase in output $r$ is defined as the referenceshare $\rho$ :

$$
\rho_{j}^{r}=\frac{\sum_{i \epsilon N} \lambda_{i j}\left(y_{r i}^{p}-y_{r i}\right)}{y_{r}^{P}-y_{r}},
$$

where

$\lambda_{i j}$ is a fraction the benchmark of DMU $j$ for DMU $i$,

$y_{r i}^{P}$ is a target output $r$ of inefficient DMU $i$,

$y_{r i}$ is observed output $r$ of inefficient DMU $i$,

$y_{r}^{P}$ is a sum of target output $r$ of all inefficient DMUs and

$y_{r}$ is the sum of observed output $r$ of all inefficient DMUs.

Calculating average value of $\rho$ for each efficient DMU enables to make their ranking.

\section{Description of variables}

The studies on R\&D and national innovation systems efficiency reveal problems with the choice of variables. They show quite little similarity concerning the sets of input variables. In most cases, $R \& D$ personnel was used as a proxy of human capital while $R \& D$ expenditures as a proxy of investment. There is less variety on output variables, publication activity indicator and high-technology exports variables were used by the majority of authors (see, Kotsemir 2013 for details).

Several international organisations like the World Bank, OECD, the European Union and Asia Pacific Economic Cooperation (APEC) developed indicators revealing the relative knowledge-intensity of economies under transition to the knowledge-based economy (Karahan 2012). Measurement of the knowledge economy is very much related to quantification of innovation performance as knowledge creation is one of the key elements of innovativeness and innovation system influences transition to a knowledge-based economy. Therefore, innovation scoreboard of the EU may be treated as a proxy of the knowledge economy. Innovation system is also an element of APEC knowledge economy indicators.

An attempt to construct European Research Area (ERA) indicators was undertaken by a group of the EU experts who proposed 'a comprehensive set of indicators to fully understand progress towards the ERA and the European knowledge economy' (European Commission 2009b). Five components of the ERA monitored at different levels of governance were identified, among others the knowledge triangle. The emphasis was placed on links between research and education and on relationships between the public and the private sector. Most of the indicators proposed for the knowledge triangle are nevertheless in the phase of development. 
Grouping indicators into input and output indicators enables to show interactions among various measures and illustrate, through output indicators, the impact of input indicators on performance of a country pursuing the knowledge-based economy. Such approach was elaborated by Karahan (2012) who identified input and output indicators for four dimensions of the knowledge economy: knowledge acquisition, knowledge production, knowledge distribution and knowledge utilization. A similar conceptual method is used in the Global Innovation Index 2013 Report dealing with innovation. Knowledge absorption is regarded as innovation input while knowledge creation, knowledge impact and knowledge diffusion are included into innovation outputs (Cornell University, INSEAD, WIPO 2013).

The choice of variables is very much limited by data availability. While OECD data bases are the most comprehensive, they do not cover information on all the EU member states. Available data sets reveal gaps also.

Table 2 covers description of input and output variables used in this study.

Input variables that have been selected for this research: expenditures on students, research and development personnel in business enterprise and intersectoral mobility of researchers illustrate interactions between vertices of the knowledge triangle. They reflect investments in knowledge creation and exchange of human resources between the sectors reflecting relations between universities and business. Links between business and educational systems are crucial for a new role of education system depicted in the knowledge triangle approach. Output variables are proxies of innovation activities results. According to the Global Innovation Index 2013, high-technology exports and scientific and technical publications belong to knowledge and technology outputs, more precisely to the knowledge diffusion and knowledge creation, respectively. Small and medium-sized enterprise (SME) introducing marketing or organisational innovations represent a proxy for non-technological innovations.

$R \& D$ process is characterized by time lags which mean that inputs do not result in immediate increase in outputs (Sharma and Thomas 2008). Therefore, the data on inputs were collected for the year 2009 or the closest available (intersectoral mobility of researcher variable being an exception due to data availability), and the data on outputs were collected for the year 2012 or the closest.

\section{Empirical results}

Pure technical efficiency

Output-oriented VRS efficiency scores are presented in Table 3. As it was expected, a high number (16 countries) are technically efficient: Estonia, Portugal, Germany, Slovenia, Denmark, France, Ireland, Sweden, Netherlands, Romania, Belgium, Czech Republic, Hungary, Italy, Latvia and Poland. Estonia being seven times a benchmark for another DMU is the most efficient peer outperforming many other DMUs. This country is likely to be a better role model for less efficient countries to emulate because its operating practices and environment match more closely to the bulk of DMUs than is the case for other Pareto-efficient DMUs which are rarely efficient peers (DMUs being benchmarks for inefficient DMUS are marked in italics).

Estonia's performance in the development of the knowledge triangle may be explained through innovative rearrangements done in the social sphere, in economy 
Table 2 Input and output variables

\begin{tabular}{|c|c|c|c|}
\hline & Indicator name & Definition & Source \\
\hline \multirow[t]{3}{*}{$\begin{array}{l}\text { Input } \\
\text { variables }\end{array}$} & $\begin{array}{l}\text { Annual expenditure on public and private educational } \\
\text { institutions per student in PPS, at tertiary level of } \\
\text { education (ISCED 5-6), based on full-time equivalents, } \\
2009 \text { or closest }\end{array}$ & $\begin{array}{l}\text { Annual expenditure on public and private educational } \\
\text { institutions per student in Purchasing Power Standards (PPS), at tertiary level of education } \\
\text { (ISCED 5-6), based on full-time equivalents }\end{array}$ & Eurostat \\
\hline & $\begin{array}{l}\text { Research and development personnel, by sectors of } \\
\text { performance, } 2009 \text { or closest }\end{array}$ & Full-time equivalent (\% of the labour force), business enterprise & Eurostat \\
\hline & Intersectoral mobility of researchers & $\begin{array}{l}\text { IM2_-Post-PhD intersectoral mobility_-Share of R2-3-4 researchers } \\
\text { who have worked as a researcher (excluding PhD) outside the } \\
\text { university or HEl sector, in \% and by panel country }\end{array}$ & MORE2 Higher Education Survey (2012) \\
\hline \multirow[t]{3}{*}{$\begin{array}{l}\text { Output } \\
\text { variables }\end{array}$} & High-technology exports (\% exports), 2012 & $\begin{array}{l}\text { This indicator is calculated as the share of exports of all high-technology } \\
\text { products of total exports. High technology products are defined as the } \\
\text { sum of the following products: aerospace, computers-office machines, } \\
\text { electronics-telecommunications, pharmacy, scientific instruments, electrical } \\
\text { machinery, chemistry, non-electrical machinery, armament. The total } \\
\text { exports for the EU do not include the intra-EU trade }\end{array}$ & Eurostat \\
\hline & $\begin{array}{l}\text { Scientific and technical publications per billion } \\
\text { PPPS GDP, } 2012\end{array}$ & $\begin{array}{l}\text { Number of scientific and engineering articles in the following fields: physics, } \\
\text { biology, chemistry, mathematics, clinical medicine, biomedical research, } \\
\text { engineering and technology, and earth and space sciences }\end{array}$ & Global Innovation Index 2013 \\
\hline & $\begin{array}{l}\text { SME introducing marketing/organisational } \\
\text { innovations (\% of SMEs) }\end{array}$ & $\begin{array}{l}\text { Number of SMEs who introduced a new marketing innovation or } \\
\text { organisational innovation to one of their markets }\end{array}$ & Innovation Union Scoreboard 2013 \\
\hline
\end{tabular}


Table 3 VRS technical efficiency scores and benchmarks

\begin{tabular}{|c|c|c|c|}
\hline \multicolumn{4}{|c|}{ Output-oriented, VRS } \\
\hline DMU & Score & Benchmark (Lambda) & $\begin{array}{l}\text { Times as a benchmark } \\
\text { for another DMU }\end{array}$ \\
\hline Estonia & 1.00 & Estonia (1.00) & 7 \\
\hline Portugal & 1.00 & Portugal (1.00) & 5 \\
\hline Germany & 1.00 & Germany (1.00) & 4 \\
\hline Slovenia & 1.00 & Slovenia (1.00) & 3 \\
\hline Denmark & 1.00 & Denmark (1.00) & 2 \\
\hline France & 1.00 & France (1.00) & 2 \\
\hline Ireland & 1.00 & Ireland (1.00) & 2 \\
\hline Sweden & 1.00 & Sweden (1.00) & 2 \\
\hline Netherlands & 1.00 & Netherlands (1.00) & 1 \\
\hline Romania & 1.00 & Romania (1.00) & 1 \\
\hline Belgium & 1.00 & Belgium (1.00) & 0 \\
\hline Czech Republic & 1.00 & Czech Republic (1.00) & 0 \\
\hline Hungary & 1.00 & Hungary (1.00) & 0 \\
\hline Italy & 1.00 & Italy (1.00) & 0 \\
\hline Latvia & 1.00 & Latvia (1.00) & 0 \\
\hline Poland & 1.00 & Poland (1.00) & 0 \\
\hline United Kingdom & 1.01 & $\begin{array}{l}\text { Estonia (0.34); France }(0.13) \text {; } \\
\text { Ireland }(0.22) ; \text { Netherlands }(0.31)\end{array}$ & 0 \\
\hline Greece & 1.04 & Estonia (0.88); Portugal (0.12) & 0 \\
\hline Finland & 1.09 & $\begin{array}{l}\text { Denmark (0.31); Germany (0.14); } \\
\text { Slovenia }(0.52) ; \text { Sweden }(0.03)\end{array}$ & 0 \\
\hline Austria & 1.16 & $\begin{array}{l}\text { Estonia }(0.10) \text {; France }(0.04) ; \\
\text { Germany }(0.40) ; \text { Ireland }(0.14) ; \\
\text { Sweden }(0.31)\end{array}$ & 0 \\
\hline Croatia & 1.23 & $\begin{array}{l}\text { Estonia }(0.43) \text {; Germany }(0.05) \text {; } \\
\text { Portugal }(0.14) \text {; Slovenia }(0.38)\end{array}$ & 0 \\
\hline Lithuania & 1.23 & Estonia (0.68); Romania (0.32) & 0 \\
\hline Slovakia & 1.37 & Estonia (0.88); Portugal (0.12) & 0 \\
\hline Spain & 1.59 & $\begin{array}{l}\text { Denmark (0.33); Germany (0.17); } \\
\text { Portugal }(0.06) \text {; Slovenia }(0.43)\end{array}$ & 0 \\
\hline Bulgaria & 2.27 & Estonia (0.92); Portugal (0.08) & 0 \\
\hline
\end{tabular}

DMUs being benchmarks for inefficient DMUS are marked in italics. Source: own calculations based on MaxDEA software

and higher educational sphere as well as increase in Estonian knowledge-based competitiveness (Kirch 2009). New economic mechanisms and new structure of institutions have been implemented to carry out a dynamic innovation model. Institutions responsible for innovation development together with bigger universities make serious efforts to create a well functioning environment for innovative developments. Estonian Development Fund was founded to promote innovative future visions, analyse Estonian future opportunities, initiate a positive change of investment traditions and develop venture capital market. Apart from a progress in institutional transformation, there is a relatively big share of collaborating innovative SMEs in Estonia and a high proportion of people with tertiary education in society.

Knowledge triangle efficiency indices

Knowledge triangle efficiency indices are presented in Fig. 2. 


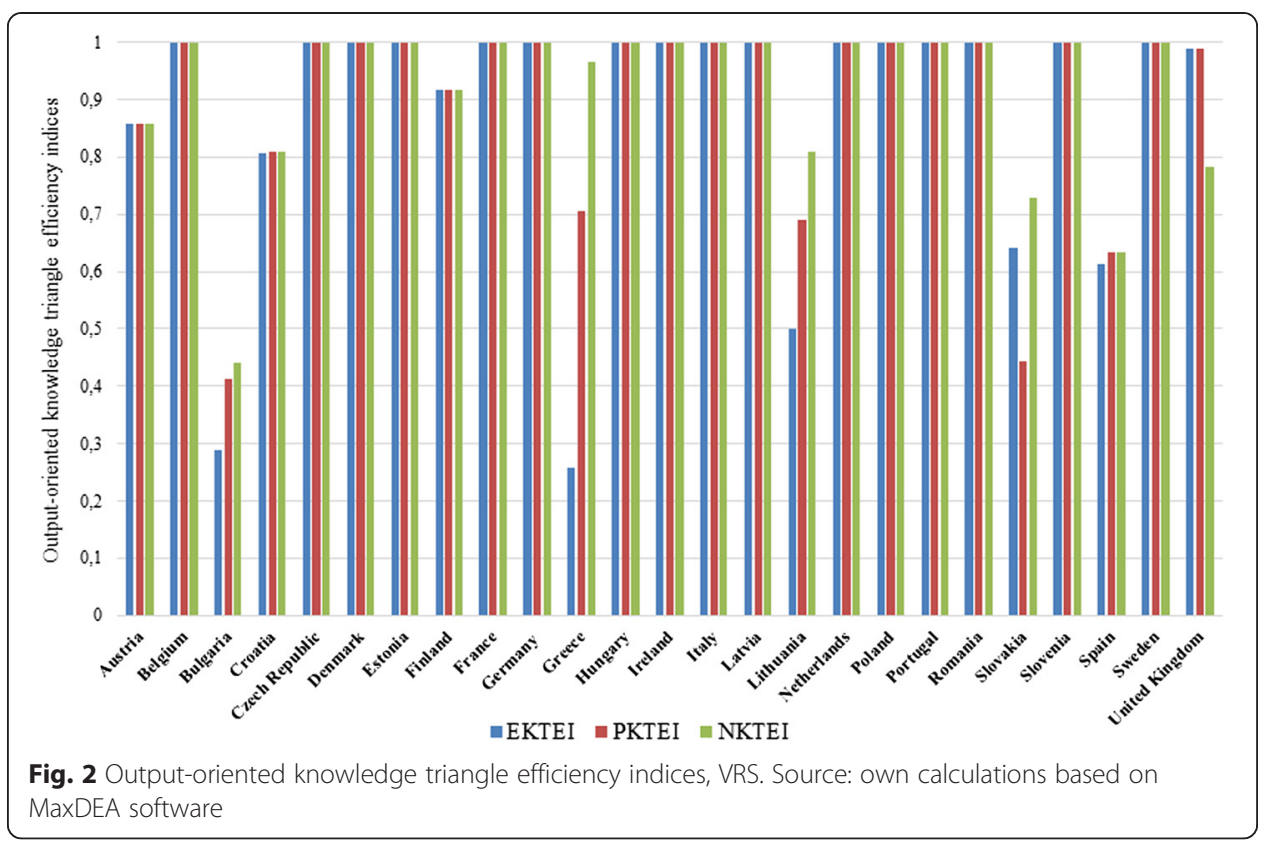

Average scores of the individual output-oriented knowledge triangle efficiency indices do not vary and are close to 0.9 , which means a high level of efficiency. Lithuania, Greece, Spain, Slovakia and Bulgaria have low average values ranging from 0.38 for Bulgaria to 0.67 in Lithuania what proves a large potential for improvement, on average. There are huge variations among the respective efficiency output indices in some countries: Bulgaria, Greece, Lithuania and Slovakia regarding the values of respective indices. The highest difference between the scores is observed for Greece where EKTEI amounts to 0.26 while NKTEI to 0.96. In Lithuania, Greece, Spain and Bulgaria, EKTEI has the lowest value while NKTEI the highest.

\section{Discrimination of efficient DMUs}

Among efficient DMUs, two groups may be identified. The first one comprises efficient DMUs which are benchmarks for inefficient DMUs; the second includes those efficient DMUs which are efficient by default. It means that they do not have characteristics which must be followed by other inefficient countries (Kumar and Gulati 2008), they are self-evaluators. Such DMUs are very productive but operate in an environment and/or use practices which are very dissimilar to the rest of DMUs.

For discrimination between DMUs belonging to the first group, the frequency in the 'benchmark set' may be used. The frequency which an efficient country shows up in the benchmark set of inefficient countries represents the extent of robustness of that country relative to other efficient country. According to this rule, Estonia is the first in ranking, followed by Portugal, Germany and Slovenia. In order to identify more precisely which DMUs are most important as benchmarks, the output-specific reference shares $\rho$ were calculated (see Table 4).

The results are slightly different to a benchmark frequency scores. A ranking is made according to the average $\rho$ value. Estonia is a referent for the largest share of the potential increase for all three outputs, with far the biggest referencing of the high technology exports (70 \%); Slovenia is ranked in the second place (Fig. 3). 
Table 4 Output-specific reference share $\rho$ for efficient DMUs being benchmarks for inefficient DMUs in percent

\begin{tabular}{lllll}
\hline DMU & $\begin{array}{l}\text { High-technology } \\
\text { exports (\% exports) }\end{array}$ & $\begin{array}{l}\text { Scientific and technical } \\
\text { publications per billion } \\
\text { PPPS GDP }\end{array}$ & $\begin{array}{l}\text { SME introducing } \\
\text { marketing/organisational } \\
\text { innovations (\% of SME) }\end{array}$ & Average rank by $\rho$ \\
\hline Estonia & 70.11 & 62.05 & 49.44 & 1 \\
Slovenia & 6.30 & 11.92 & 14.38 & 2.3 \\
Portugal & 7.75 & 7.98 & 3.51 & 3 \\
Germany & 4.19 & 5.46 & 7.95 & 4.3 \\
Denmark & 3.29 & 6.49 & 7.91 & 4.6 \\
Romania & 4.97 & 3.31 & 2.45 & 6 \\
Sweden & 1.83 & 1.50 & 2.84 & 7 \\
Ireland & 0.39 & 0.16 & 2.40 & 8.6 \\
Netherland & 0.18 & 0.13 & 3.27 & 8.6 \\
France & 0.31 & 0.23 & 1.72 & 9 \\
\hline Source: own & Cali & & &
\end{tabular}

Source: own calculations based on Torgersen et al. (1996)

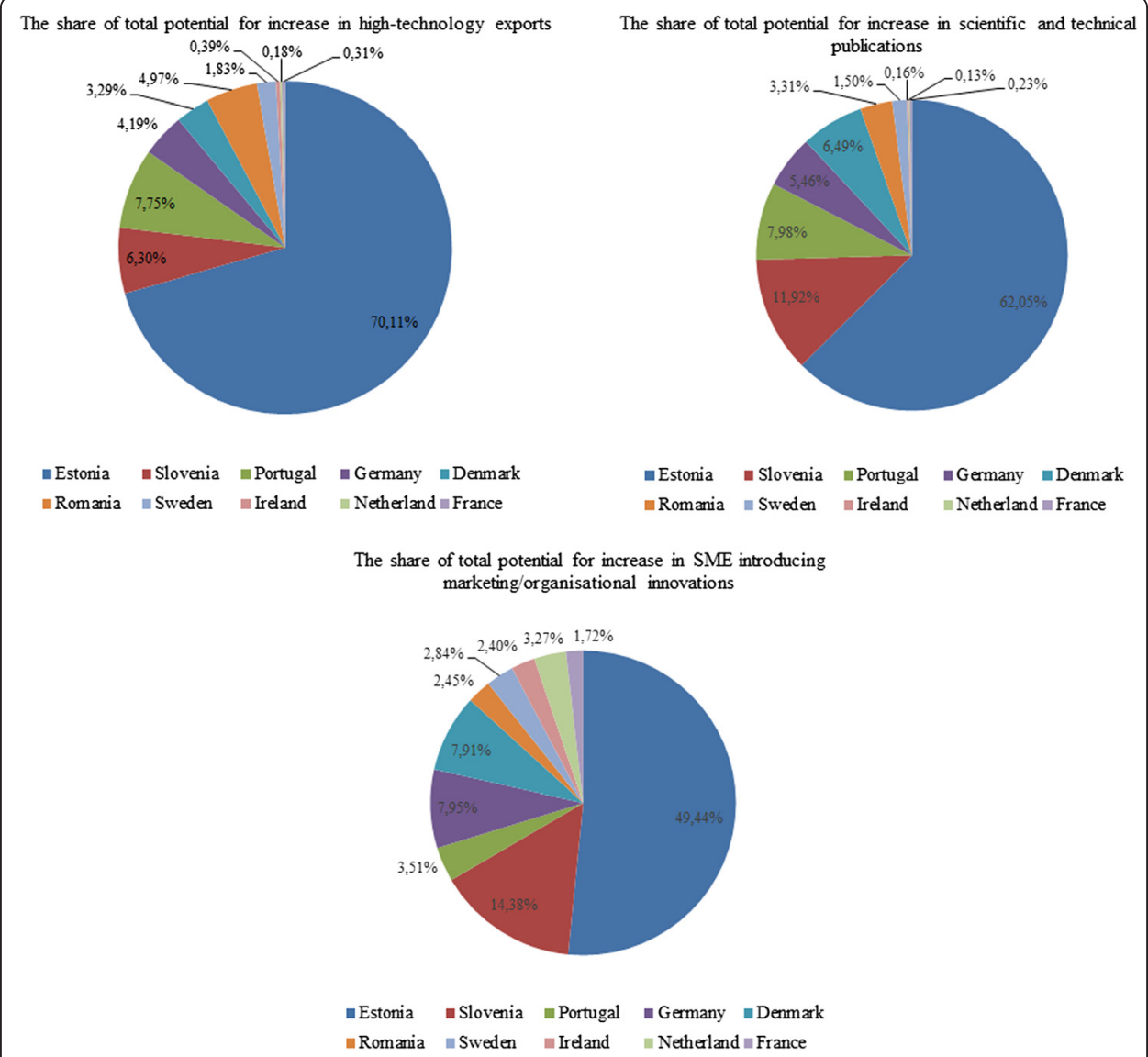

Fig. 3 The share of total potential for increase in outputs. Source: own calculations based on Torgersen et al. (1996) 
These two countries refer to more than a half of the potential increase of all three outputs. Therefore, they should be investigated in more detail to learn about best practices in the policy-making concerning the knowledge triangle. Other efficient DMUs, although are the benchmarks, either reference few inefficient DMUs or reveal too many differences from inefficient DMUs or finally these inefficient DMUs have small potentials for efficiency improvement.

\section{Scale efficiency and returns to scale}

Table 5 presents scale efficiency scores, returns to scale (RTS) and intensity of scale inefficiency. Scale efficiency captures the impact of scale size on the productivity of the DMU concerned. The larger the divergence of scale efficiency ratings, the lower the value of scale efficiency and the more adverse impact of scale size on productivity (Thanassoulis 2001). Information about returns to scale is very important for managerial decisionmaking. If a DMU is operating at a point where increasing returns to scale hold, it makes sense to increase its scale size as an increase in inputs will be more than compensated by a rise in output levels. Additionally, intensity of scale inefficiency may be calculated according to the formula below (Guzik 2009):

Table 5 Scale efficiency, returns to scale and intensity of scale inefficiency

\begin{tabular}{|c|c|c|c|}
\hline $\mathrm{DMU}$ & Scale efficiency score & RTS & Intensity of scale inefficiency $S_{0}$ \\
\hline Belgium & 1 & Constant & 0.00 \\
\hline Estonia & 1 & Constant & 0.00 \\
\hline France & 1 & Constant & 0.00 \\
\hline Germany & 1 & Constant & 0.00 \\
\hline Hungary & 1 & Constant & 0.00 \\
\hline Ireland & 1 & Constant & 0.00 \\
\hline Italy & 1 & Constant & 0.00 \\
\hline Romania & 1 & Constant & 0.00 \\
\hline Slovenia & 1 & Constant & 0.00 \\
\hline Lithuania & 0.98 & Decreasing & 0.08 \\
\hline Bulgaria & 0.97 & Decreasing & 0.09 \\
\hline Greece & 0.96 & Decreasing & 0.15 \\
\hline Portugal & 0.96 & Decreasing & 0.13 \\
\hline Slovakia & 0.96 & Decreasing & 0.13 \\
\hline Czech Republic & 0.91 & Decreasing & 0.11 \\
\hline Croatia & 0.89 & Decreasing & 0.05 \\
\hline Sweden & 0.87 & Decreasing & 0.13 \\
\hline Austria & 0.85 & Decreasing & 0.10 \\
\hline Spain & 0.85 & Decreasing & 0.11 \\
\hline Finland & 0.83 & Decreasing & 0.14 \\
\hline Latvia & 0.83 & Increasing & -0.10 \\
\hline United Kingdom & 0.8 & Decreasing & 0.13 \\
\hline Poland & 0.74 & Increasing & -0.09 \\
\hline Denmark & 0.72 & Decreasing & 0.24 \\
\hline Netherlands & 0.58 & Decreasing & 0.32 \\
\hline
\end{tabular}

Source: Own calculations based on MaxDEA software. Countries with increasing returns to scale (RTS) are in italics. 


$$
S_{0}=\frac{\sum_{j=1}^{J} \lambda_{0}^{*}-1}{\sum_{j=1}^{J} \lambda_{0}^{*}+0},
$$

where

$\lambda_{0}^{*}$ is an optimal lambda coefficient of $\mathrm{DMU}_{0}$.

This measure takes the value $[-1,+1]$, it is equal to 0 for a DMU with constant returns to scale. For an ineffective DMU, the closer the value of $S_{0}$ measure to -1 or +1 , the greater is the intensity of scale inefficiency.

Nine countries reveal constant returns to scale, others with the exception of Poland and Latvia reveal decreasing returns to scale what would suggest decrease in their activities. However, if intensity of scale inefficiency is taken into account, it turns out that the $S_{O}$ values are very small (Denmark and the Netherlands being exceptions), close to 0 , thus insignificant and not really meaningful for policymakers. A small variation of $S_{O}$ values could be explained by the character of inputs and outputs which are presented in the form of indices, not in the form of absolute values.

\section{Conclusion}

According to the new growth theory, the knowledge-based economy gives almost unlimited opportunities for growth. Consequently, creation and usage of knowledge should be a basis for development policies addressed to various economic branches and implemented at different levels of governance.

Higher education is the cornerstone of the knowledge-based economy. Closer links between education and business which should result in fostering innovation activities, and ultimately, the knowledge-based economy and society are the basis of the knowledge triangle concept. Educational system and especially the higher education need to be transformed to meet the requirements of the business sector and society regarding development of innovation skills. These postulates are the core of the knowledge triangle EU policy framework which stipulates support of both knowledge demand and supply (vertices of the triangle) and knowledge circulation.

Most EU member states make efforts to achieve better results concerning innovativeness through the knowledge triangle policy using limited resources. The measurement of efficiency of the EU knowledge triangle policy is therefore important for future development of evidence-based policy recommendations.

In this study, efficiency of the knowledge triangle policy in $25 \mathrm{EU}$ member states was presented by application of DEA. Under DEA output-oriented VRS model, 16 countries are technically efficient, variation among the efficiency scores is small (coefficient of variation amounts to $25 \%$ ). This may signify overall effectiveness of the EU knowledge triangle policy. A more detailed analysis of output efficiency indices reveals that there are countries: Bulgaria, Greece, Lithuania, Spain and Slovakia, which have a large potential for improvement. Bulgaria has $62 \%$ potential improvement on average, Slovakia $40 \%$, Spain $37 \%$, Greece $36 \%$ and Lithuania $33 \%$. In all these countries with the exception of Spain, there is also a huge differentiation among respective output efficiency indices. In three countries: Bulgaria, Greece and Lithuania, the values of EKTEI index are the lowest which suggests that in these countries, a problem of a relatively low level of high-tech exports should be addressed in the first place as actual knowledge triangle 
policy mix does not give good results concerning their ability to export innovative goods.

A closer analysis of efficient DMUs shows that two countries: Estonia and Slovenia, refer to more than a half of the potential increase of all three outputs. Therefore, the knowledge triangle policy-making in these two countries should be studied in detail to draw conclusions for inefficient countries. It is especially valid regarding Estonia which is a benchmark for seven inefficient DMUs (out of nine) and on average refers to $60 \%$ of the potential increase of the outputs.

Lack of an appropriate scale is not a source of inefficiency in most of cases, Denmark and the Netherlands being an exception, because intensity of scale inefficiency is low.

Obtained results should however be treated with caution because they are influenced by the choice of variables which is limited by data availability. Future research should incorporate other variable sets in order to assess how they affect efficiency of the knowledge triangle policy and make appropriate comparison of results. Another research avenue may be focused on comparisons of results in time to find out if and to what extent environmental features affect efficiency of the EU knowledge triangle policy.

\section{Endnotes}

${ }^{1}$ Based on Chen et al. (2011)

${ }^{2}$ Description of the CCR model is based on Cooper, Seiford and Zhu (2011).

\section{Appendix}

DEA may be perceived as a representation of a 'production process' where the resources required are usually the inputs while the outcomes are the outputs. If the DEA problem presents a benchmarking problem, the inputs are 'less-the-better' type of performance measures and the outputs are usually 'more-the-better' type of performance measures (Cook, Tone and Zhu 2014). Depending on whether inputs or outputs are controllable, different measures of efficiency are appropriate. Output orientation is appropriate when outputs are controllable while input orientation is justified when inputs are controllable. According to output orientation 'a DMU is Pareto efficient if it is not possible to raise anyone of its output levels without lowering at least another one of its output levels and/or without increasing at least one of its input levels', input orientation means that 'a DMU is Pareto efficient if it is not possible to lower anyone of its input levels without increasing at least another one of its input levels and/or without lowering at least one of its output levels' (Thanassoulis 2001).

Typical objectives for carrying out DEA are the following (Golany and Roll 1989):

- Identification of the sources and amounts of relative inefficiency in each of the compared units,

- Ranking of the units by their efficiency outcomes,

- Evaluation of management of the compared units,

- Evaluation of the effectiveness of 'programs' or policies which are outside the control of the units,

- Creation of a quantitative basis for reallocating resources among the units under evaluation,

- Identification of efficient units, 
- Analysis and scrutiny of prevailing standards on specific input-output relations against actual performance and

- Comparison and contrasting of results from previous studies.

Apart from the objectives outlined above, DEA models identify target input-output levels which would make DMUs Pareto-efficient and efficient peers that ineffective DMUs could emulate to improve their performance.There are three main phases to carry out DEA (Golany and Roll 1989):

- Definition and selection of DMUs to enter analysis,

- Determination of input and output factors and

- Application of the DEA models and analysis of outcomes.

There are minimal prior assumptions on input-output relations in DMUs. Relations between them should be 'isotonic' which means that an increase in any input should not result in a decrease in any output (Golany and Roll 1989). Correspondence of inputs and outputs should be based on a relationship of exclusivity and exhaustiveness which means that inputs, and they alone must influence the output levels and only of the outputs being used in the assessment (Thanassoulis 2001). DMUs under scrutiny should perform the same tasks and have similar objectives, perform under the same set of 'market conditions' what means that DMUs should be homogenous (see, e.g. Dyson et al. 2001 on this subject). The number of units should be at least twice the number of the sum of inputs and outputs (Golany and Roll 1989).

There are two basic models of DEA: the Charnes, Cooper and Rhodes (CCR) model and the Banker, Charnes and Cooper (BCC) model.

CCR known also as constant returns to scale (CSR) model is the original DEA model developed by Charnes, Cooper and Rhodes in 1978 (Charnes et al. 1978). The implication of the CSR assumption is that the scale of operation of a DMU has no impact on productivity.

In CCR model, there are $n$ DMUs to be evaluated ${ }^{2}$. Each DMU consumes varying amounts of $m$ different inputs to produce s different outputs. Specifically, $\mathrm{DMU}_{j}$ consumes $x_{i j}$ of input $i$ and produces amount $y_{r j}$ of output $r$

For output-oriented CCR model, the objective function is the following:

$$
\begin{aligned}
& \operatorname{Min} \frac{\sum_{i}{ }_{i}{ }_{i} x_{i o}}{\sum_{r} u_{r} y_{r 0}} \\
& \text { subject to } \\
& \frac{\sum_{i}{ }_{i} x_{i} x_{i o}}{\sum_{r} u_{r} y_{r 0}} \gg 1 \text { for } j=1, \ldots, n, \\
& u_{r}, v_{i} \gg \varepsilon>0 \text { for all } i \text { and } r
\end{aligned}
$$

where $\varepsilon>0$ is the non-Archimedean element defined to be smaller than any positive real number and $v_{i}$ and $u_{r}$ are the values of inputs and outputs, respectively.

Using duality in linear programming, one can derive an equivalent envelopment model (output oriented, constant returns to scale): 


$$
\max h+\varepsilon\left(\sum_{i=1}^{m} s_{i}^{-}+\sum_{r=1}^{s} s_{r}^{+}\right)
$$

subject to

$$
\begin{array}{cc}
\sum_{j=1}^{n} x_{i j} \lambda_{j}+s_{i}^{-}=x_{i o} & i=1,2, \ldots, m ; \\
\sum_{j=1}^{n} y_{r j} \lambda_{j}-s_{r}^{+}=h y_{r o} \quad r=1,2, \ldots, s ; \\
\lambda, s_{i}^{-}, s_{r}^{+} \geq 0 \forall i, j, r \quad j=1,2, \ldots, n,
\end{array}
$$

where

$s_{r}^{-}$and $s_{r}^{+}$are slack variables,

$\lambda$ is an intensity weight or benchmark coefficient and

$\frac{1}{h}$ is the technical output efficiency.

A DMU is Pareto efficient if $h=0, s_{r}^{-}=0$ and $s_{r}^{+}=0$. After calculating the technical efficiency for each inefficient DMU, the most efficient point on the frontier may be identified as the target. The total adjustment of the inefficient DMU is a sum of radial adjustments of outputs and amount of slack. Slack is a distance of the shift along the frontier from the radially projected point to a point at the practical maximum level of output. The practical maximum output level is called the 'target output level' (Coelli et al. 2005).

In contrast to the CCR model, the BCC model developed by Banker et al. (1984) takes into account possible returns-to-scale evaluations (increasing, constant or decreasing) and therefore is called the VRS model. A production correspondence is said to exhibit increasing returns to scale (IRS) if a radial increase in input levels leads under Pareto efficiency to a more than proportionate radial increase in output levels. If the radial increase in output levels is less than proportionate, we have decreasing returns to scale (DRS) and otherwise we have constant returns to scale (CRS) (Thanassoulis 2001).

Envelopment BCC model (output oriented) is stated as follows (Banker et al. 2011):

$$
\min z+\varepsilon\left(\sum_{i=1}^{m} s_{i}^{-}+\sum_{r=1}^{s} s_{r}^{+}\right)
$$

subject to

$$
\begin{aligned}
& \sum_{j=1}^{n} x_{i j} \lambda_{j}+s_{i}^{-}=x_{i o} \quad i=1,2, \ldots . m ; \\
& \sum_{j=1}^{n} y_{r j} \lambda_{j}-s_{r}^{+}=z y_{r o} \quad r=1,2, \ldots . s ; \\
& \sum_{j=1}^{n} \lambda_{j}=1 \quad j=1,2, \ldots, n ;
\end{aligned}
$$

$$
\lambda_{j}, s_{i}^{-}, s_{r}^{+} \geq 0 \forall i, j, r \quad j=1,2, \ldots, n,
$$

where $\frac{1}{z}$ is by definition the pure technical output efficiency of $\mathrm{DMU}_{\mathrm{jo}}$.

A pure notion is to signal that technical efficiencies are 'net' of any scale effect (Thanassoulis 2001). The impact of scale size on efficiency is measured by scale 
efficiency. It measures the divergence between the efficiency rating of a DMU under CRS and VRS, respectively.

Scale output efficiency is defined as follows:

Technical ouput efficiency of $\mathrm{DMU}_{\mathrm{jo}}$ $\overline{\text { Pure technical ouput efficiency of } \mathrm{DMU}_{\text {jo }}}$

The empirical part of research is based on MaxDEA Basic 6.6 software, http:// www.maxdea.cn/MaxDEA.htm, developed by G. Cheng and Z. Qian.

\section{Author details}

${ }^{1}$ Polish Science Contact Agency PolSCA, Polish Academy of Sciences, rue du Trône 98, B-1050 Brussels, Belgium.

Electrical and Computer Engineering Department, University of Patras, University Campus, Rio 26504, Greece.

Received: 23 February 2015 Accepted: 12 November 2015

Published online: 24 November 2015

\section{Additional file}

Additional file 1: Translation of the abstract into Arabic.

\section{Author details}

${ }^{1}$ Polish Science Contact Agency PolSCA, Polish Academy of Sciences, rue du Trône 98, B-1050 Brussels, Belgium.

${ }^{2}$ Electrical and Computer Engineering Department, University of Patras, University Campus, Rio 26504, Greece.

Received: 23 February 2015 Accepted: 12 November 2015

Published online: 24 November 2015

References

Aristovnik A (2012) The relative efficiency of education and R\&D expenditures in the new EU member states. J Bus Econ Manag 13(5):832-848. doi:10.3846/16111699.2011.620167

Aristovnik A (2014a) Development of the information society and its impact on the education sector in the EU: efficiency at the regional (nuts 2) level. Turk Online J Educ Technol 13(2):54-60

Aristovnik A (2014b) Efficiency of the R\&D sector in the EU-27 at the regional level: an application of DEA. Lex Localis Journal of Local Self-Government 12(3):519-531. doi:10.4335/12.3.519-531(2014)

Banker RD, Cooper WW, Seiford LM, Zhu J (2011) Returns to scale in DEA. In: Cooper WW, Seiford LM, Zhu J (eds) Handbook on data envelopment analysis. Springer, New York, pp 41-70

Banker R, Charnes A, Cooper WW (1984) Some models for estimating technical and scale inefficiencies in data envelopment analysis. Manag Sci 30(9):1078-1092

Charnes A, Cooper WW, Rhodes E (1978) Measuring efficiency of decision making units. Eur J Oper Res 2:429-444

Chen Ch-P HJ-L, Yang C-H (2011) An international comparison of R\&D efficiency of multiple innovative outputs: the role of the national innovation system. Innov Manag Policy Pract 13(3):341-360. doi:10.5172/impp.2011.13.3.341

Chien T, Hu J-L (2007) Renewable energy and macroeconomic efficiency of OECD and non-OECD economies. Energy Policy 35:3606-3615. doi:10.1016/j.enpol.2006.12.033

Coelli TJ, Prasada Rao DS, O'Donnell Ch J, Battese GE (2005) An introduction to efficiency and productivity analysis. Springer, New York

Conclusions of the Council and the Representatives of the Governments of the Member States, 14344/09, Brussels, 20 October 2009

Cooper WW, Seiford LM, Zhu J (2011) Data envelopment analysis: history, models and interpretations. In: Cooper WW Seiford LM, Zhu J (eds) Handbook on data envelopment analysis. Springer, New York, pp 1-40

Cornell University, INSEAD, WIPO (2013) The global innovation index 2013: the local dynamics of innovation. Geneva, Ithaca, and Fontainebleau

Cortright J (2011) New growth theory, technology and learning: a practitioner's quide. Rev Econ Dev Lit Pract 4

da Cruz NF, Marques RC (2014) Revisiting the determinants of local government performance. Omega. Int J Manag Sci 44:91-103. doi:10.1016/j.omega.2013.09.002

Dyson RG, Allen R, Camanho AS, Podinovski W, Sarrico CS, Shale EA (2001) Pitfalls and protocols in DEA. Eur J Oper Res 132(2):245-259. doi:10.1016/S0377-2217(00)00149-1

Edler J (2009) Demand policies for innovation in EU CEE countries. Manchester Business School Working Paper, 579. http://www.mbs.ac.uk/cgi/apps/research/working-papers/view/?wld=186. Accessed 6 June 2014

European Commission (2004) The Europe of knowledge 2020: a vision for university -based research and innovation. Conference Proceedings. Liège, Belgium, April 25-28

European Commission (2009a) Reinvent Europe through innovation, recommendations by a business panel on future EU innovation policy., http://ec.europa.eu/enterprise/policies/innovation/files/panel_report_en.pdf. Accessed 21 July 2014

European Commission (2009b) ERA indicators and monitoring expert group report. Publications Office of the European Union, Luxembourg

European Institute of Innovation and Technology (EIT) (2012) Catalysing innovation in the knowledge triangle. Practices from the EIT knowledge and innovation communities 
Golany B, Roll Y (1989) An application procedure for DEA. Omega Int J Manag Sci 17(3):237-250

Hervás Soriano F, Mulatero F (2009) Connecting the dots. How to strengthen the EU knowledge economy. Joint research centre-Institute for Prospective Technological Studies, European communities

Guzik B (2009) Podstawowe modele DEA w badaniu efektywności gospodarczej I społecznej. Wydawnictwo Uniwersytetu Ekonomicznego w Poznaniu, Poznań

Karahan Ö (2012) Input-output indicators of knowledge-based economy and Turkey. J Bus Econ Finance 1(2):21-36

Kirch A (2009) On the perspectives of the implementation of knowledge triangle based on Lisbon strategy in Estonia. Eur Integration Stud 3:36-41

Kotsemir MN (2013) Measuring national innovation systems efficiency-a review of DEA approach. Basic research program working papers series: science, technology and innovation WP BRP 16/STI/2013. National research university higher school of economics

Kumar S, Gulati N (2008) An examination of technical, pure technical, and scale efficiencies in Indian public sector banks using data envelopment analysis. Eurasian J Bus Econ 1(2):33-69

Maassen P, Stensaker B (2011) The knowledge triangle, european higher education policy logics and policy implications. High Educ 61:757-769. doi:10.1007/s10734-010-9360-4

OECD (1996) The knowledge-based economy

OECD (2001) The well-being of nations: the role of human and social capital

Porter ME (1990) The competitive advantage of nations. Free Press, New York

Potočnik J (2009) The significance of the knowledge triangle for the future of Europe. Conference the knowledge triangle shaping the future of Europe, Gothenburg, 1st September

Shapiro H, Haahr JH, Bayer I, Boekholt P (2007) Background paper on innovation and education for the european commission Sharma S, Thomas VJ (2008) Inter-country R\&D efficiency analysis: an application of data envelopment analysis. Scientometrics 76(3):483-501. doi:10.1007/s11192-007-1896-4

Thanassoulis E (2001) Introduction to the theory and application of data envelopment analysis. Springer, New York

Tong Ch SP (1997) China's spatial disparity within the context of industrial production efficiency: a macro study by the data-envelopment analysis (DEA) system. Asian Econ J 11(2):207-217. doi:10.1111/1467-8381.00032

Torgersen AM, Førsund FR, Kittelsen SAC (1996) Slack-adjusted efficiency measures and ranking of efficient units. J Prod Anal 7:379-398

Submit your manuscript to a SpringerOpen ${ }^{\circ}$ journal and benefit from:

- Convenient online submission

Rigorous peer review

- Immediate publication on acceptance

- Open access: articles freely available online

- High visibility within the field

- Retaining the copyright to your article

Submit your next manuscript at $>$ springeropen.com 